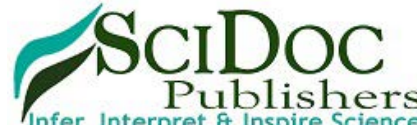

International Journal of Dentistry and Oral Science (IJDOS)

ISSN: $2377-8075$

\title{
Management of Isolated Areas of Gingival Recession using Lateral Sliding Flap Sandwiched with Sub Epithelial Connective Tissue Graft - A Case Report

Rajeev Arunachalam*, Vini Rajeev, Sivadas Ganapathy, Vaishnavi Vedam

Senior Lecturer, Faculty of Dentistry, Asian Institute of Medicine, Science and Technology (AIMST) University, Malaysia.

\section{Abstract}

\begin{abstract}
Receding gum line is common condition with diverse etiology, one being periodontitis and the other principally linked to mechanical factors, mainly tooth brushing. Mucogingival surgical management have better prognosis if reason for recession being mechanical factors in contrast to periodontal disease induced etiology. Prognosis based classification proposed by Miller suggest a good to excellent for type I and II whereas for remaining types the prognosis is less. Among various periodontal plastic surgery procedures, a sub epithelial connective tissue graft [SCTG] do have better predictability. This case report presents a clinical scenario where lateral sliding flap procedures was employed in conjunction with Subepithial connective tissue graft in class III type of Millers recession with a keyobjective to benefit periodontal health through reconstruction of damaged /lost tissues thereby improving patient's appearance. Post-op evaluation, demonstrated an upsurge in the soft tissue volume and increase of keratinized tissue.
\end{abstract}

Keywords: Coverage; Epithelium; Graft; Recession.

\section{Introduction}

Recession of gingiva can happen to people of all ages. It occurs even if a person takes good care of their teeth. Periodontal health, esthetics and comfort are compromised when marginal tissue recessions are present. Receding gums can pose problem for health of the dentition. With regard to health of the periodontium, the recession act as a local transforming factor for initiation and development of periodontal disease, as the normal gingival scalloping outline is affected making it more prone for increased plaque accumulation also leading to compromised esthetics [1]. End result will loss of patients comfort due to dentinal hypersensitivity caused by exposed root surface that ensues [2]. Esthetics, sensitivity of root, prevention and management of root caries, periodontal disease are among the various indications where root coverage procedures are employed $[3,4]$. Numerous surgical methods are used for root coverage such as pedicle graft - coronally advanced flap, laterally positioned and double - papilla, free gingival and sub epithelial connective tissue graft, guided tissue generation or an amalgamation of these techniques. However the selection of appropriate technique is grounded on assessment of factors such as width and height of the defect and state of interproximal gingiva and underlying bone which are determining factor to grasp a good prognosis.

Laterally positioned flap [LPF] mostly used on mandibular teeth for isolated recession, where the neighboring tooth act as a donor site for the flap to be positioned laterally to cover the defect. The coronally positioned flap [CPF] technique used on maxilla is one of the pioneers meant for root coverage with the advantage of not being technique sensitive and doesn't require procuring the donor tissue thereby reducing the morbidity of the same. Eventhough the above mentioned when used alone presented varying rates of success, the predictability of the outcome is questionable. Sub Epithelial connective tissue graft [SCTG] for root coverage was first proposed by Langer and Langer (1985) who initially outlined the protocol was later modified with variations for achieving success [5]. SCTG is the most studied technique because of final color accomplished and which presents the most predictable root coverage $[6,7]$. Marginal tissue recession was proposed by Miller in 1985 [8] where a higher degree of soft tissue as well as bone loss were noticed on Class IV followed by class III where

*Corresponding Author:

Dr. Rajeev Arunachalam MDS,

Senior Lecturer, Department of Periodontics, Faculty of Dentistry, AIMST University, JalanBedongSemeling, Kedah, DarulAman, Malaysia 08100.

Tel: + 60164055204

E-mail: rajeevarun80@gmail.com

Received: September 22, 2020

Accepted: October 21, 2020

Published: November 10, 2020

Citation: Rajeev Arunachalam, Vini Rajeev, Sivadas Ganapathy, Vaishnavi Vedam. Management of Isolated Areas of Gingival Recession using Lateral Sliding Flap Sandwiched with Sub Epithelial Connective Tissue Graft - A Case Report. Int J Dentistry Oral Sci. 2020;7(11):981-984. doi: http://dx.doi.org/10.19070/2377-8075-20000195

Copyright: Rajeev Arunachalam ${ }^{\circ} 2020$. This is an open-access article distributed under the terms of the Creative Commons Attribution License, which permits unrestricted use, distribution and reproduction in any medium, provided the original author and source are credited. 
the grade of prognosis is much lesser in terms of root coverage achieved after surgery.

The present case report depicts two case scenarios using SCTG in combination with laterally positioned flap as well as to demonstrate the success predictability of the technique when indicated.

\section{Case Report}

A male patient 22yrs old , systemically health, non-smoking, presented to Department of Periodontics with a chief complaints sensitivity at tooth \#37 [Figure 1] to hot and cold food stuffs.

After examination, the probable etiological factors were demarcated as faulty and traumatic tooth brushing technique. Clinically, the tooth presented a marginal tissue recession of about $3 \mathrm{~mm}$ from cemento-enamel junction [CEJ], with of probing depth not more than $2 \mathrm{~mm}$ on the mesial root of second mandibular molar. Lateral Sliding Flap [LSF]coupled with Sub Epithelial connective tissue graft [SCTG] was planned forroot coverage.

Prior to surgery patient was advised to rinse with $0.12 \%$ aqueous solution chlorhexidine digluconate. Thorough scaling and root planing was done on \#37 under local anesthesia [LA] to get rid of the infected and exposed cementum.

Preparation of recipient site is done through horizontal incisionsdirected into the gingival margin and interdental papilla of the 36 tooth region [donor site]. A vertical relieving incision is made in an apical course from the gingival margin at the distal surface of the donor site to a sulcular position, which to some extent surpasses that of the defect to be concealed. [Figure 2]. A partial thickness flap is raised conserving the periosteumunharmed. [Figure3].

Once the receptor site was prepared, the SCTG was obtained from the palate; through the window technique two parallel incisions were given: one perpendicular to the tooth axis and the other parallel to the bone surface, extending up to the preferred graft height [Figure 4].

The graft was adjusted onto the recipient site [Figure5]and stabilized with absorbable sutures (5-0 Vicryl, J\&J Ethicon, USA). Inorder to position the flap coronally over the graft and to enhance graft's stabilization on the recipient area a suspensory silk suture was given along with complementary sutures [Figure 6]. The donor site was also sutured with 4-0 silk thread.

Patient was cleared with post-operative instructions and prescriptions for five days to avoid post-operative discomfort. Patient was recalled after one week for check-up. The surgical site was inspected for uneventful healing. There was no post-operative complication and healing was satisfactory. The defect created at the donor site heals by secondary intention. Patient was educated to use soft toothbrush for plaque control in surgical area. Patient was monitored on weekly schedule postoperatively, to ensure good oral hygiene in the surgical site. The re-evaluation of this area at 6 months follow-up showed no recurrence [Figure.7, Figure 8].

\section{Discussion}

Currently there are various techniques for root coverage but it

Figure 1. Gingival Recession in relation to mesial root of lower mandibular molar [37].

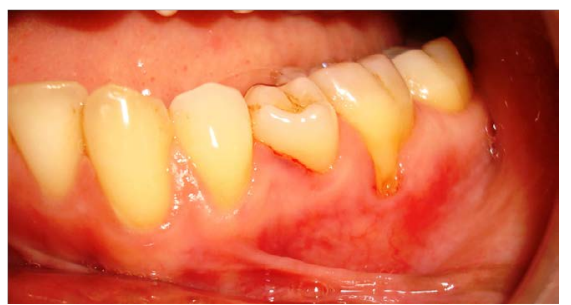

Figure 2. Preparation of recipient site with incisions using lateral sliding flap.

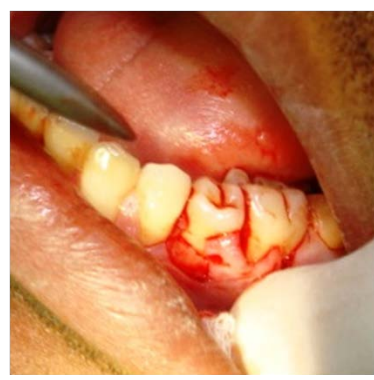

Figure 3. Recipient Bed prepared.

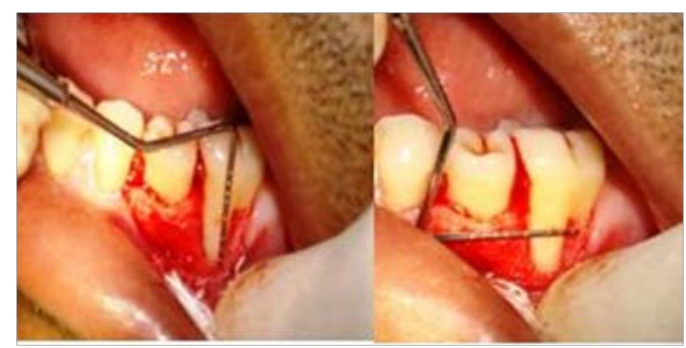


Figure 4. Sub Epithelial Connective Graft Harvested Using Trap Door Technique.

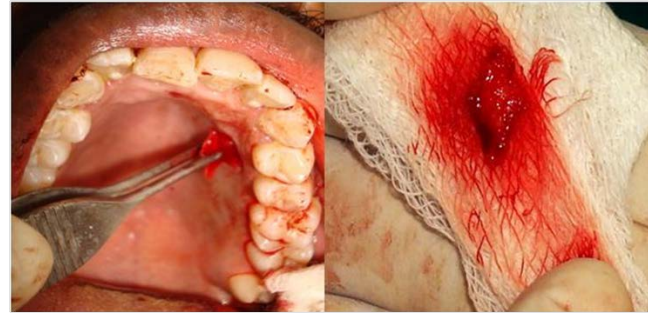

Figure 5. Graft placed on recipient 37 tooth region.

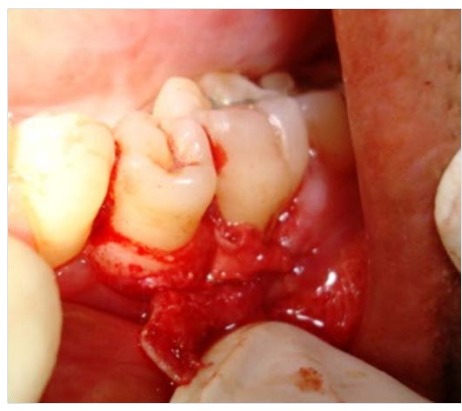

Figure 6. Sutures placed covering the recession.

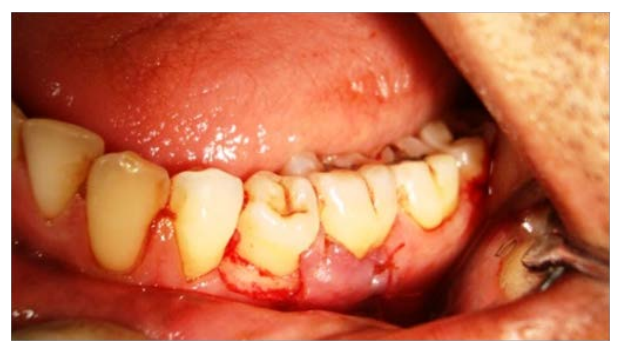

Figure 7.3 weeks post-operative .

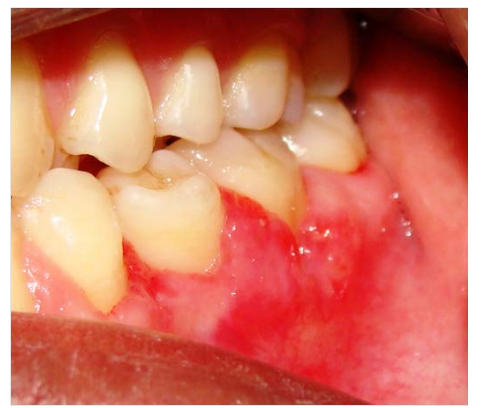

Figure 8. One year post-operative.

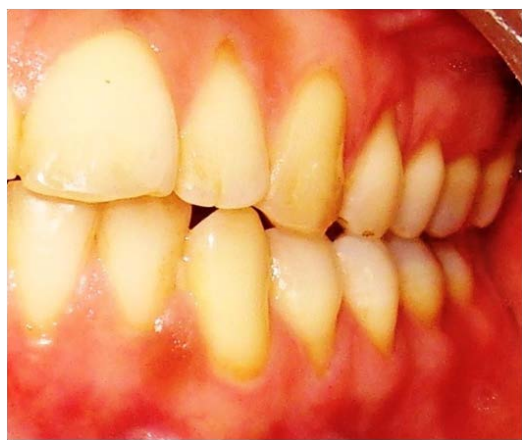

is often challenging to foresee the accomplishment rate of root coverage techniques since the coverage depends on numerous factors, including the type and location of the recession and the method used. The root coverage attained in the current study, using LSF shared with SCTG, were around 60\%-85\% and were in agreement with the outcomes of previous studies [9]. The case designated in the current report was the Miller class III case with substantial interproximal bone loss, with isolated deep and wide defects. The involved teeth also had aninadequatequantity of keratinized gingiva, thus causing difficulty in coronally repositioning the flap to completelyshield the tissue graft.Even though it has been proved on literature that the tissue graft can be left exposed in certain circumstances [10], the clinical risk of having an uneven gingival margin cannot be ruled out [3]. Therefore, LSF looks like 
to be a better option to coronally advanced flap [CAF] in these progressive gingival recession cases. Lateral sliding flap can make sure that connective tissue graft is fully concealed by the gingival flap and also enhances healing by providing adequate blood supply laterally to upsurge the plasmatic circulation [11]. LSF is usually advised in isolated areas of recession when adequate length, width and depth of keratinized tissue is available on the neighboring donor area of gingival recession [12].

In the present clinical report the SCTG was positioned $2.5-3 \mathrm{~mm}$ above the bone level in the interproximal area which was centered on the notion of biological width supporting the tooth and not merely following the cementoenamel junction level, which is the anticipated level of full root coverage as the complete coverage of the root in Miller class III cases is not normally expected.

Based on study done by Esteibar JR et.al full coverage of root in Miller class III recession could only be attained under specific circumstances where there is proper integrity if the interdental gingiva, loss of the interproximal bone not more than $3 \mathrm{~mm}$, the thickness of the graft greater than $2 \mathrm{~mm}$ and the width of the recession defect not exceeding $3 \mathrm{~mm}$ [13]. For achieving complete root coverage one of the most important criteria should the dimension and stability of the laterally sliding flap because adequate blood supply to the coronal portion the flap is ensured if dimensions are wider.Literatures from previous studies have revealed that with suitable case selection the LSF is an effective technique in handling isolated recession scenarios [14].

In this clinical report the esthetic outcome post -surgically was agreeable for the patient. The ancillary outcome variables were reduced root sensitivity, post-operative patient pain recession reduction, clinical attachment gain andkeratinized tissue gain. Three to nine months post-operative clinical results were promising with no recurrence. Therefore laterally sliding flap coupled with subepithelial connective tissue graft is a highly foreseeable and effective root coverage surgical procedure.

\section{Conclusion}

The present case report demonstrates successful management of miller's class III gingival recession using Lateral sliding flap with
SCTG. $80 \%$ root coverage was achieved. Final outcome of the present case report showcases that LSF when sandwiched with SCTG can be an effective management option in attaining soft tissue coverage of root as well as improvement in clinical attachment level in Miller's class III recession defects.

\section{References}

[1]. Fontanari LA, Rodrigues MR, Scremin EI, Kitano MS, Sampaio JE, Trevisan Junior W. Enxerto de tecidoconjuntivosubepitelial: umaalternativaemcirurgiaplástica periodontal. Perionews. 2009:131-5.

[2]. Holbrook T, Ochsenbein C. Complete coverage of the denuded root surface with a one-stage gingival graft. Int J Periodontics Restorative Dent. 1983;3(3):8-27. PubmedPMID: 6358084.

[3]. Bouchard P, Malet J, Borghetti A. Decision-making in aesthetics: root coverage revisited. Periodontol 2000. 2001;27:97-120. Pubmed PMID: 11551302.

[4]. Harris RJ. The connective tissue and partial thickness double pedicle graft: a predictable method of obtaining root coverage. J Periodontol. 1992 May;63(5):477-86. Pubmed PMID: 1527693.

[5]. Langer B, Langer L. Subepithelial connective tissue graft technique for root coverage. J Periodontol. 1985 Dec;56(12):715-20. Pubmed PMID: 3866056.

[6]. Oliver RC, Brown LJ, Löe H. Periodontal diseases in the United States population. J Periodontol. 1998 Feb;69(2):269-78. PubmedPMID: 9526927.

[7]. Steffens JP, Santos FA, Pilatti GL. Cirurgiasmucogengivais para recobrimento radicular: o enxerto de conjuntivosubepitelialcomotécnica de sucesso para defeitosisolados. Dental Science. 2008;2(7):207-14.

[8]. Miller PD Jr. A classification of marginal tissue recession. Int J Periodontics Restorative Dent. 1985;5(2):8-13.Pubmed PMID: 3858267.

[9]. Hwang D, Wang HL. Flap thickness as a predictor of root coverage: a systematic review. J Periodontol. 2006 Oct;77(10):1625-34. Pubmed PMID: 17032103.

[10]. Han JS, John V, Blanchard SB, Kowolik MJ, Eckert GJ. Changes in gingival dimensions following connective tissue grafts for root coverage: comparison of two procedures. J Periodontol. 2008 Aug;79(8):1346-54. Pubmed PMID: 18672983.

[11]. Gordon HP, Sullivan HC, Atkins JH. Free autogenous gingival grafts. II. Supplemental findings--histology of the graft site. Periodontics. 1968 Jun;6(3):130-3. Pubmed PMID: 5241945.

[12]. Guinard EA, Caffesse RG. Treatment of localized gingival recessions. Part I. Lateral sliding flap. J Periodontol. 1978 Jul;49(7):351-6. PubmedPMID: 279662.

[13]. Esteibar JR, Zorzano LA, Cundín EE, Blanco JD, Medina JR. Complete root coverage of Miller Class III recessions. Int J Periodontics Restorative Dent. 2011 Jul-Aug;31(4):e1-7. PubmedPMID: 21837295.

[14]. Jagannathachary S, Prakash S. Coronally positioned flap with or without acellular dermal matrix graft in the treatment of class II gingival recession defects: A randomized controlled clinical study. ContempClin Dent. 2010 Apr;1(2):73-8. Pubmed PMID: 22114387. 